\title{
HENRYK MACHAJEWSKI, GRONOWO. EIN GRÄBERFELD DER WIELBARK-KULTUR IN WESTPOMMERN, FUNDACJA MONUMENTA ARCHAEOLOGICA BARBARICA, WARSZAWA-SZCZECIN-GDAŃSK 2013
}

W 2013 r. na rynku wydawniczym ukazała się długo oczekiwana przez badaczy zajmujących się okresem wpływów rzymskich monografia Gronowo. Ein Gräberfeld der WielbarkKultur in Westpommern autorstwa dr. hab. Henryka Machajewskiego z Uniwersytetu Gdańskiego. Wydana przez Fundację Monumenta Archaeologica Barbarica, Muzeum Narodowe w Szczecinie, Fundację Uniwersytetu Gdańskiego oraz Państwowe Muzeum Archeologiczne w Warszawie książka zawiera kompleksowe zestawienie wyników badań, jakimi objęte zostało cmentarzysko kultury wielbarskiej w Gronowie.

Nekropolia kurhanowa w Gronowie należy do bardzo ważnych stanowisk kultury wielbarskiej. Wschodnią częścią stanowiska jest cmentarzysko płaskie, którego początki użytkowania datowane są od przełomu okresu przedrzymskiego i rzymskiego, a więc fazy A3/B1, po młodszy okres rzymski - fazę B2b-B2c. Zachodnia część nekropoli to cmentarzysko kurhanowe, na którym najstarsze pochówki pochodzą ze schyłku fazy B1 i fazy B2, większość $\mathrm{z}$ nich datowana jest jednak na fazy B2/C1-C1a. Stanowisko to zatem jest dowodem przetrwania użytkowania położonych na zachód od dolnego Powiśla cmentarzysk kultury wielbarskiej w ciągu fazy B2/C1-C1. W okresie późnorzymskim następuje tam zmiana kulturowa związana z osadnictwem kultury dębczyńskiej. Cmentarzysko w Gronowie jest zróżnicowane zarówno pod względem form pochówków, jak i stosowanego tam obrządku pogrzebowego, który ma charakter birytualny. Duże możliwości poznawania struktury społecznej ludności kultury wielbarskiej dało odkrycie na nekropoli w Gronowie mogił wielopochówkowych. Znamienne jest również bogate wyposażenie grobów w importy rzymskie, ostrogi, ozdoby ze złota i srebra oraz brązu z aplikacjami z metali szlachetnych.

Książka Gronowo. Ein Gräberfeld der Wielbark-Kultur in Westpommern jest osiemnastą publikacją z serii Monumenta Archaeologica Barbarica - i w swym układzie nawiązuje do poprzednich jej tomów. Składa się ona z 210 stron i tradycyjnie zawiera wstęp, rozbudowany katalog, analizę materiału oraz tablice ze szczegółowymi rycinami zabytków i obiektów. Dodatkowo można tam znaleźć obszerną analizę osadniczą oraz trzy aneksy z wynikami badań z zakresu antropologii fizycznej i materiałoznawstwa. Rozdział VI, Naturwissenschaftliche Untersuchungen, zawiera następujące aneksy: VI.1. Annex I: Franciszek Różnowski, Antropologische Untersuchungen der Knochenreste aus dem Gräberfeld von Gronowo; VI.2. An- 
nex IIa: Jerzy Maik, Die Textilien aus den Grabhügeln von Gronowo; VI.3 Annex IIb: Maria Cybulska, Tomasz Florczak, Rekonstruktion des Prachtmantels von Gronowo.

We wstępie książki Henryk Machajewski dokładnie lokalizuje stanowisko w Gronowie oraz opisuje historię jego badań. Autor podaje, iż doskonale zachowane ze względu na usytuowanie w środku lasu gronowskie kurhany zapadły w świadomości miejscowej ludności, która teren ten nazywała „Pötterkaveln” lub „Pöterfichten”. Nazwa ta miała związek ze znajdowaną tam ceramiką. Pierwsze, amatorskie badania na dziewięciu kurhanach przeprowadził tam kaznodzieja H.G. Plato ze Złocieńca w latach 1881-1890. Następne prace na gronowskiej nekropolii przeprowadzono przy okazji budowy dróg w latach 1926 oraz 1939-1940. Odkryto wówczas i zlokalizowano obszar grobów płaskich - teren ten został jednak ponownie obsadzony lasem. Systematyczne badania wykopaliskowe na cmentarzysku w Gronowie przeprowadzone zostały z inicjatywy Muzeum Narodowego w Szczecinie przez Ryszarda i Danutę Wołągiewiczów w latach 1973-1977. W wyniku tych badań, spośród znanych pierwotnie 30 przebadano 29 zachowanych kurhanów i ujawniono ślady osadnictwa. Pracom archeologicznym prowadzonym przez Wołągiewiczów towarzyszyły badania interdyscyplinarne: antropologiczne - prowadzone przez Franciszka Różnowskiego, badania tekstyliów przez Jerzego Maika i Lise Bender Jørgensen, oraz palinologiczne - prowadzone przez Krystynę Konecką-Betlay. Henryk Machajewski we wstępie przedstawia również bazę materiałową będącą efektem wspomnianych badań - na niej opierał się, tworząc rzeczoną monografię.

Badania prowadzone na cmentarzysku w Gronowie stały się podstawą wielu publikacji (m.in.: R. Wołagiewicz (1976), Gronowo 1973, badania na cmentarzysku kurhanowym z okresu wpływów rzymskich. Materiały Zachodniopomorskie, t. 19; R. Wołągiewicz (1974), Gronowo 1974, badania na kurhanowym cmentarzysku kultury wielbarskiej. Materiaty Zachodniopomorskie, t. 20; R. Wołągiewicz (1976), Cmentarzysko kurhanowe kultury wielbarskiej w Gronowie w świetle badań w latach 1973-1976. Materiały Zachodniopomorskie, t. 22; J. Maik (1977), Tkaniny wykopaliskowe z cmentarzyska w Gronowie, woj. koszalińskie. Materiały Zachodniopomorskie, t. 22; F. Różnowski (1976), Analiza antropologiczna szczątków kostnych wydobytych na cmentarzysku w Gronowie, pow. Drawsko Pomorskie (stanowisko 1). Materiały Zachodniopomorskie, t. 19), mających głównie charakter sprawozdawczy i dotyczących odrębnie analiz archeologicznych, antropologicznych czy z zakresu włókiennictwa. Prace te do dziś stanowią podstawową bazę źródłową dla zagadnień dotyczących cmentarzyska w Gronowie. Niekwestionowaną wadą owych opracowań jest jednak ich rozbicie, dlatego aby prześledzić wyniki badań nekropolii w Gronowie, czytelnik był zmuszony do sięgnięcia do kilku różnych publikacji.

W monografii Gronowo. EinGräberfeld der Wielbark-Kultur in Westpommern H. Machajewski łączy wszystkie wyniki badań i poddaje je dokładnej analizie, co skutkuje usystematyzowaniem wiedzy na temat owego stanowiska. Nieocenioną zaletą tej książki jest zamieszczony w rozdziale drugim obszerny katalog, który prezentuje materiały i obiekty pochodzące z cmentarzyska, osady, pola ornego. Dodatkowo ujęte zostały także ślady osadnictwa kultury łużyckiej. Stworzenie tego katalogu wymagało niewątpliwie znacznego wkładu pracy, nie jest on bowiem kopią i automatycznym połączeniem w całość istniejących wcześniej sprawozdań. Autor opracowania ponadto posiłkuje się w jego tworzeniu dokumentacją archiwalną z badań prowadzonych przez H.G. Plato. Uporządkował on tym samym materiały pochodzące z kurhanów rozpoznanych przez tegoż badacza. Efektem tych zabiegów jest przyporząd- 
kowanie inwentarzy do poszczególnych grobów, które dotychczas przypisane były jedynie do jednej z czterech grup kurhanów wydzielonych przez Plato (A-D), oraz uzupełnienie katalogu o brakujące, nieopublikowane wcześniej materiały i informacje. Tym samym w stosunku do publikacji z lat 1973-1976 autorstwa R. Wołągiewicza opracowanie H. Machajewskiego porządkuje i uzupełnia katalog o materiały z kurhanu 1/groby (dalej: gr.) 1,2,4, kurhanu 2, kurhanu 3/gr. 1, 2, kurhanu 4/gr. 1, kurhanu 5/gr. 1, kurhanu 7/gr. 1, kurhanu 8/gr. 1, kurhanu 9/gr. 1, kurhanu 10/gr. 2, 3, kurhanu 11/gr. 1, kurhanu 12, kurhanu 15 oraz kurhanów 23-30. Wprowadzenie do literatury „nowych” materiałów ze stanowiska w Gronowie stanowi istotny wkład do dalszych studiów nad kulturą wielbarską. Znaczenie takie niewątpliwie ma również zawartość rozdziału trzeciego, który zawiera szczegółowy opis i analizę materiału zabytkowego oraz obiektów ze stanowiska w Gronowie. Autor posiłkuje się w nim najnowszymi opracowaniami typologicznymi danej kategorii zabytków oraz przywołuje liczne analogie z obszaru środkowoeuropejskiego Barbaricum. W części analitycznej autor przyjrzał się nie tylko kwestiom formalnym, dotyczącym morfologii zabytków, lecz także podjął się ich wnikliwej interpretacji, wskazując m.in. na liczne wpływy kulturowe powodujące zmiany lub pojawienie się danego przedmiotu. Podniósł również kwestie społeczne oraz symboliczne. Wyczerpujący wykład uzupełniony jest o liczne tabele, mapy prezentujące rozmieszczenie zabytków na stanowisku oraz ryciny, dzięki czemu wyniki badań są bardziej czytelne i przyswajalne. Kolejną częścią składową książki jest rozdział dotyczący funkcjonowania osady w Gronowie, którą H. Machajewski umieszcza w określonych ramach chronologicznych i na tle sieci osadniczej. Autor wymieniając kolejne etapy rozwoju niniejszej osady, obszernie opisuje przyczyny owych zmian. Rozdział piąty to spis literatury, spis rycin oraz skorowidz stanowisk, które są nieodłącznym elementem każdej publikacji i ogromną pomocą dla czytelnika zainteresowanego zgłębieniem problematyki dotyczącej nie tylko omawianego stanowiska, lecz także problemów związanych z tym zagadnieniem.

Zaletą opracowania stanowiska w Gronowie są znajdujące się w nim trzy aneksy, będące podsumowaniem wyników badań interdyscyplinarnych prowadzonych na stanowisku w Gronowie. Pierwszym $\mathrm{z}$ nich są ujęte $\mathrm{w}$ formie tabelarycznej wyniki badań antropologicznych wykonanych przez Franciszka Różnowskiego, związanego ze stanowiskiem w Gronowie już od czasu badań w latach 70. XX w. Autorem kolejnego aneksu jest Jerzy Maik, specjalista z zakresu włókiennictwa, który również współpracował z Ryszardem i Danutą Wołągiewiczami. Aneks zawiera szczegółową analizę fragmentów tkanin z kurhanów gronowskich, uzupełnioną o bardzo dobrej jakości fotografie pozwalające czytelnikowi na wnikliwą analizę materiałoznawczą tekstyliów. Pozytywnym zaskoczeniem są wirtualne rekonstrukcje tkanin, w tym płaszcza ceremonialnego, wykonane przez Marię Cybulską oraz Tomasza Florczaka. Do stworzenia wizualizacji wykorzystano m.in. technikę cyfrową 3D, dzięki czemu łatwo trafiają one do świadomości czytelnika, który może się przyjrzeć strukturze pledu oraz przekonać się o rzeczywistym wyglądzie części garderoby, jaką był płaszcz.

Opracowanie wieńczą bogate tablice przedstawiające rysunki i fotografie inwentarzy z pochówków oraz same obiekty z gronowskiej nekropoli. Ryciny w znacznej części opierają się na tych pochodzących $\mathrm{z}$ opracowań Wołągiewiczów; w pewnych przypadkach, jak podkreślał autor, wymagały one przerysowania zgodnie z funkcjonującymi obecnie standardami. Tablice uzupełnione są jednak o materiały niepublikowane wcześniej, co daje zupełnie nowe możliwości poznawcze. 
Reasumując: książka Gronowo. Ein Gräberfeld der Wielbark-Kultur in Westpommern rzuca nowe światło na zakorzenione już w świadomości archeologów wyniki badań na stanowisku w Gronowie. Dokonaniem godnym najwyższej aprobaty jest uporządkowanie, uzupełnienie oraz zestawienie przez H. Machajewskiego wszystkich wyników badań, ich dogłębna analiza i interpretacja, co pozwala na całościowe spojrzenie na problematykę funkcjonowania społeczności wielbarskiej na gronowskim kompleksie osadniczym. Omawiana monografia w znaczący sposób uzupełnia tym samym obecny stan wiedzy o społeczności kultury wielbarskiej.

\section{Emilia Smótka-Antkowiak}

Instytut Prahistorii, Uniwersytet im. A. Mickiewicza

ul. Umultowska 89D, 61-614 Poznań, Poland

emiliasmolka@wp.pl 